\title{
Pemanfaatan Aplikasi Mobile untuk Pencatatan Keuangan pada Usaha Banten di Bhuana Asri Dalung
}

\author{
Rosalia Hadi $^{1 *}$, I Gede Nika Wirawan², I Gusti Ngurah Ady Kusuma ${ }^{3}$,Ni Luh Gede Pivin Suwirmayanti ${ }^{4}$ \\ ${ }^{1,2}$ Prodi Sistem Informasi, Institut Teknologi dan Bisnis STIKOM Bali \\ ${ }^{3,4}$ Prodi Sistem Komputer, Institut Teknologi dan Bisnis STIKOM Bali \\ ${ }^{1}$ rosa@stikom-bali.ac.id, ${ }^{2}$ nika_wirawan@stikom-bali.ac.id, ${ }^{3}$ ady_kusuma@stikom-bali.ac.id, ${ }^{4}$ pivin@ stikom-bali.ac.id
}

\begin{abstract}
Banten is a tool offered by Hindus as a form of gratitude to God Almighty for his bestowed blessings. Every Hindu family is obliged to provide Banten as a means of daily religious ceremonies. Therefore people who can make Banten are needed to meet these needs. That is what prompted Mrs Kadek Suli to open this business. Mrs Kadek Suli's offering business is located at Br. Bhuana Asri Dalung, North Kuta District, Badung Regency. The business, which was started in 2015, provides various Banten needs, such as Canang, Meghan, Sodaan, etc. This service activity aims to help Mrs Kadek Suli know the profit/loss of her business and add to Mrs Kadek Suli's insight regarding the use of mobile applications other than for entertainment, namely Mrs Kadek Suli can also use it for financial records and making monthly reports, Mrs Kadek Suli never takes notes the amount of income or expenditure, so you do not know the profit/loss of the business. Through this service activity, Mrs Kadek Suli can use a mobile application to record her daily income and expenses and make monthly reports, so that you can find out the profit/loss from her business. The stages of this service activity began with outreach to partners about the importance of information technology and financial recording, then continued with a training stage in Android-based financial applications to record income and expenditure and make monthly reports. The final stage of the activity is monitoring and evaluation. The results obtained from this activity are that now Mrs Kadek Suli knows the use of information technology and can use mobile applications for financial recording and monthly reports.
\end{abstract}

Keywords: Banten, Financial Record, Mobile Application

Abstrak

Banten merupakan sarana yang dipersembahkan oleh Umat Hindu sebagai bentuk rasa terima kasih kepada Tuhan Yang Maha Esa atas berkat yang telah dilimpahkannya. Setiap keluarga beragama Hindu wajib menghaturkan banten sebagai sarana upacara keagamaan sehari-hari, oleh karena itu dibutuhkan orang yang mampu membuat banten untuk memenuhi kebutuhan tersebut. Itulah yang mendorong Ibu Kadek Suli untuk membuka usaha ini. Usaha pembuatan banten Ibu Kadek Suli ini berlokasi di Br. Bhuana Asri Dalung, Kecamatan Kuta Utara, Kabupaten Badung. Usaha yang mulai dirintis tahun 2015 ini menyediakan berbagai keperluan banten, seperti canang, segehan, sodaan dan lain sebagainya. Kegiatan pengabdian ini bertujuan untuk membantu Ibu Kadek Suli mengetahui laba/rugi usahanya dan menambah wawasan Ibu Kadek Suli mengenai pemanfaatan aplikasi mobile selain untuk hiburan, yaitu Ibu Kadek Suli juga dapat menggunakannya untuk pencatatan keuangan dan pembuatan laporan bulanan, Ibu kadek Suli tidak pernah melakukan pencatatan jumlah pemasukan maupun pengeluran, sehingga tidak mengetahui laba/rugi usahanya. Melalui kegiatan pengabdian ini Ibu Kadek Suli dapat menggunakan aplikasi mobile untuk mencatat pemasukan maupun pengeluaran hariannya dan membuat laporan bulanan, sehingga dapat diketahui laba/rugi dari usahanya. Tahapan kegiatan pengabdian ini dimulai dari sosialisasi kepada mitra mengenai pentingnya teknologi informasi dan pencatatan keuangan, kemudian dilanjutkan dengan tahapan pelatihan pemanfaatan aplikasi keuangan berbasis android untuk mencatat pemasukan maupun pengeluaran serta pembuatan laporan bulanan. Tahapan akhir kegiatan adalah monitoring dan evaluasi, dimana hasil yang didapatkan dari kegiatan ini adalah kini Ibu Kadek Suli mengetahui pemanfaatan teknologi informasi dan dapat memanfaatkan aplikasi mobile untuk pencatatan keuangan dan pembuatan laporan bulanan.

Kata Kunci: Banten, Pencatatan Keuangan, Aplikasi Mobile

*Penulis Korespondensi : Rosalia Hadi 


\section{PENDAHULUAN}

Smartphone merupakan perangkat seluler yang dilengkapi dengan sistem operasi layaknya komputer. Smartphone dapat mengimplementasikan berbagai bentuk multimedia seperti halnya komputer, hanya saja keunggulannya adalah smartphone memiliki mobilitas yang tinggi dan dapat dioperasikan secara lebih efektif (Ismanto, dkk, 2017). Aplikasi smartphone memiliki banyak kegunaan, misalnya saja dapat digunakan sebagai sarana untuk mencari pengetahuan, media komunikasi, hiburan, dan menyimpan data (Nasution, dkk, 2017). Penggunaan lainnya yang juga penting adalah pemanfaatannya dalam dunia usaha.

Usaha Kecil dan Menengah (UKM) di berbagai negara termasuk di Indonesia merupakan salah satu penggerak perekonomian rakyat yang tangguh (Gunanto, 2015). Salah satu faktor penting yang tidak boleh dilupakan para pengusaha dalam melakukan kegiatan pengembangan usaha adalah pembukuan (Rinandiyana, dkk, 2020). Apabila sebuah usaha ingin bertahan lama, maka pencatatan keuangan atau pembukuan merupakan salah satu elemen yang tidak boleh diabaikan karena kegiatan bisnis tentunya memerlukan pencatatan keuangan/pembukuan agar setiap transaksi yang terjadi dapat diketahui secara jelas (Andarsari and Dura, 2018).

Salah satu UKM yang membutuhkan pencatatan keuangan atau pembukuan dalam menjalanan usahanya adalah usaha pembuatan banten Ibu Kadek Suli yang berlokasi di Br. Bhuana Asri Dalung, Kecamatan Kuta Utara, Kabupaten Badung. Usaha yang mulai dirintis tahun 2015 oleh Ibu Kadek Suli ini menyediakan berbagai keperluan banten, seperti canang, segehan, sodaan, pejati, daksina, tipat kelanan dan lain sebagainya. Selain menjual perlengkapan banten sehari-hari, Ibu Kadek Suli juga membuat banten upacara agama sesuai dengan pesanan pelanggan.

Penghasilan yang diterima oleh Ibu Kadek Suli tidak menentu dalam satu bulan. Hal ini tergantung pada hari raya di bulan tersebut. Saat menjelang hari raya umat Beragama Hindu, maka penghasilan Ibu Kadek Suli akan meningkat. Ibu Kadek Suli tidak mengetahui dengan pasti jumlah laba atau rugi yang didapatkan, karena tidak pernah melakukan pencatatan jumlah pemasukan maupun pengeluran. Oleh karena itu, pada kegiatan ini diberikan pelatihan pencatatan keuangan dan pembuatan laporan bulanan dengan menggunakan aplikasi mobile berbasis Android.

Aplikasi serupa telah digunakan untuk pencatatan keuangan yang diberi nama e-Dompet dengan hasil dapat mempermudah dan membantu seseorang dalam mencatat dan mengelola pemasukan serta pengeluaran keuangan dengan baik dan cermat (Juhardi dan Khairullah, 2019).

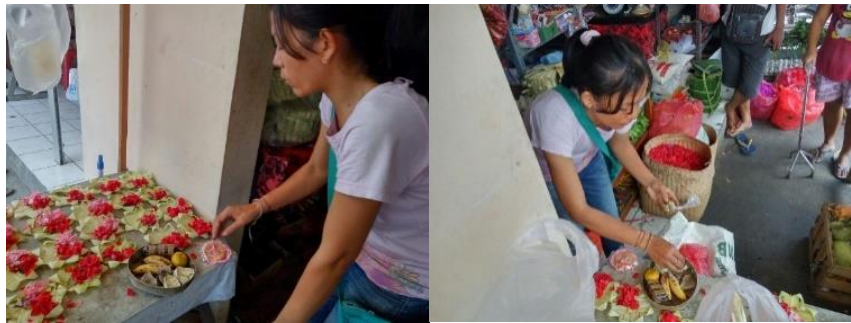

Gambar 1. Proses Pembuatan Banten

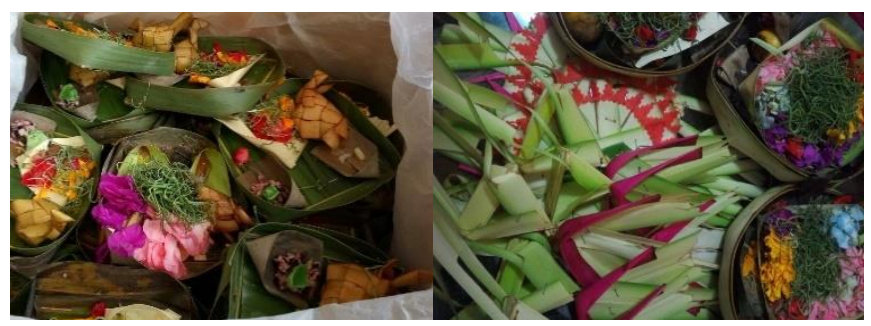

Gambar 2. Banten

Berdasarkan hasil analisa yang dilakukan, maka dapat dituliskan permasalahan mitra adalah sebagai berikut:

1. Ibu Kadek Suli dan keluarga mempunyai smartphone Android dan telah terbiasa menggunakannya, namun hanya sebatas tujuan komunikasi dan sarana hiburan. Ibu Kadek Suli belum mengetahui aplikasi mobile untuk pencatatan keuangan.

2. Ibu Kadek Suli tidak melakukan pencatatan terhadap jumlah pemasukan maupun pengeluaran, sehingga tidak mengetahui dengan pasti jumlah laba atau rugi dari usahanya.

\section{METODE}

Kegiatan dimulai dari sosialisasi kegiatan, pelatihan pemanfaatan aplikasi mobile untuk pencatatan keuangan sampai dengan evaluasi.
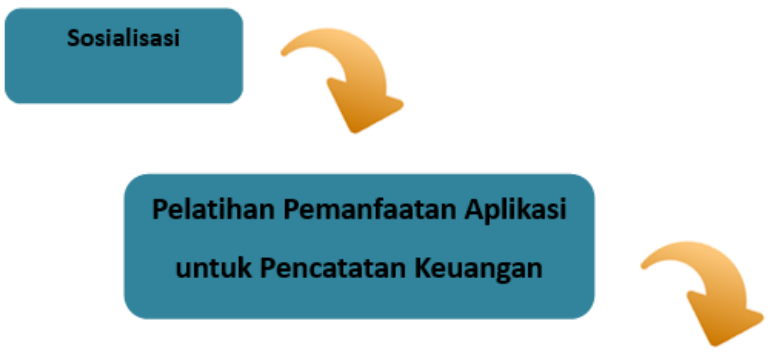

Evaluasi

Gambar 3. Alur Kegiatan 
1. Sosialisasi dilakukan dengan mendatangkan peserta dalam pertemuan. Peserta adalah Ibu Kadek Suli dan keluarga yang terlibat dalam usaha. Pada tahapan sosialisasi akan disampaikan pendahuluan seperti pentingnya pemanfaatan teknologi informasi dalam kehidupan sehari-hari, pengenalan aplikasi pencatatan keuangan berbasis android dan penjelasan mengenai pentingnya pencatatan keuangan bagi suatu usaha termasuk usaha banten Ibu Kadek Suli.

2. Pelatihan pemanfaatan aplikasi mobile berbasis Android untuk pencatatan keuangan berupa pencatatan pemasukan dan pengeluaran serta pembuatan laporan bulanan untuk mengetahui laba/rugi usahanya.

3. Evaluasi dilakukan untuk mengukur tingkat pemahaman mitra terhadap kegiatan pelatihan yang telah dilakukan.

\section{HASIL DAN PEMBAHASAN}

Kegiatan Pengabdian Masyarakat ini dilakukan pada Usaha Pembuatan Banten Ibu Kadek Suli dalam hal pencatatan keuangan sehingga dapat diketahui laba/rugi usahanya. Tahapan yang dilakukan pada kegiatan pengabdian masyarakat ini diawali dengan sosialisasi, dilanjutkan dengan kegiatan pemanfaatan aplikasi mobile untuk pencatatan keuangan sampai dengan tahapan evaluasi.

\section{Lokasi Pengabdian}

Usaha Pembuatan Banten Ibu Kadek Suli terletak di Banjar Bhuana Asri Dalung, Kecamatan Kuta Utara, Kabupaten Badung. Ibu Kadek Suli membuat dan menjual bebagai macam keperluan banten upacara.

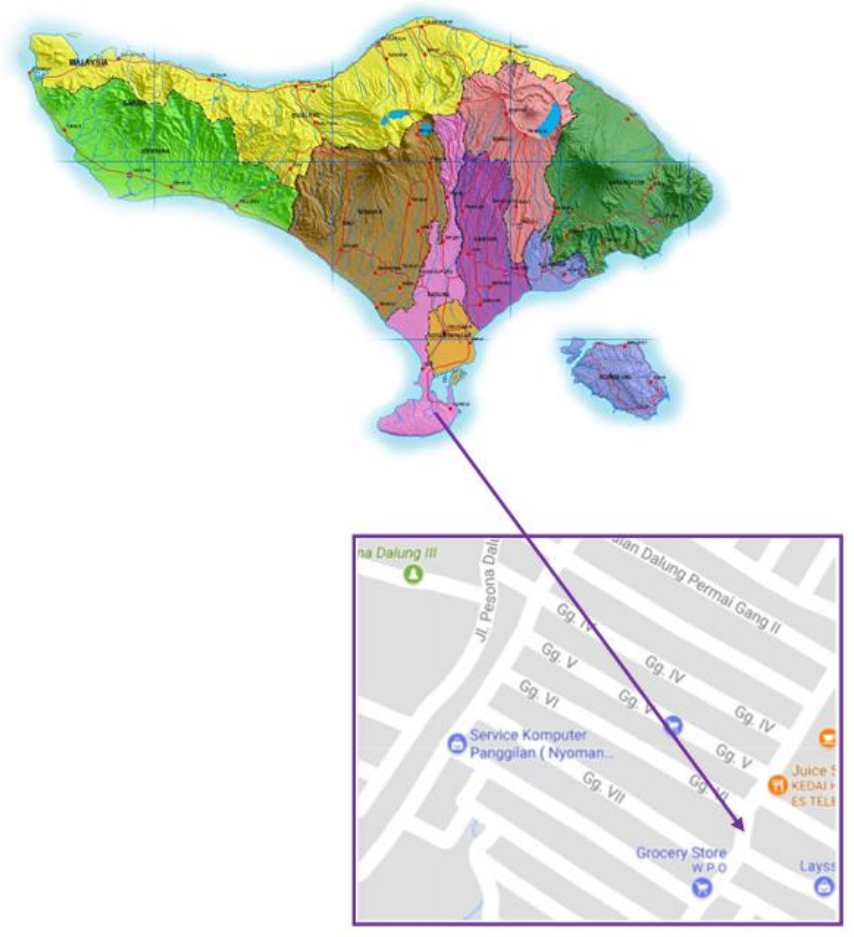

Gambar 4. Lokasi Pengabdian

\section{Pelaksanaan Pengabdian}

Pelaksanaan kegiatan pengabdian masyarakat yang dilakukan pada Usaha Banten Ibu Kadek Suli dibagi dalam tahapantahapan sebagai berikut:

1. Sosialisasi

Pada tahap sosialisasi dilakukan perkenalan dari personal dengan mitra dan dilakukan penyampaian rencana kegiatan yang dilakukan selama pelatihan. Pada tahap ini disampaikan pula dampak positif dari pemanfaatan aplikasi mobile.

2. Pemanfaatan Aplikasi Mobile untuk Pencatatan Keuangan Fungsionalitas dari aplikasi mobile untuk pencatatan keuangan terlihat pada gambar 5.

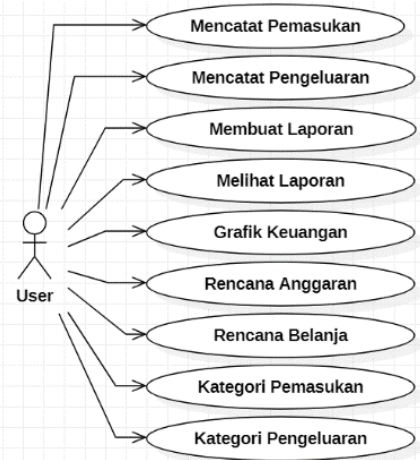

Gambar 5. Use Case Diagram

Pada pelatihan pemanfataan aplikasi mobile untuk pencatatan keuangan dilakukan beberapa kegiatan sebagai berikut:

a. Membuka aplikasi mobile untuk pencatatan keuangan dan pembuatan laporan bulanan seperti tampak pada gambar 6 berikut ini.

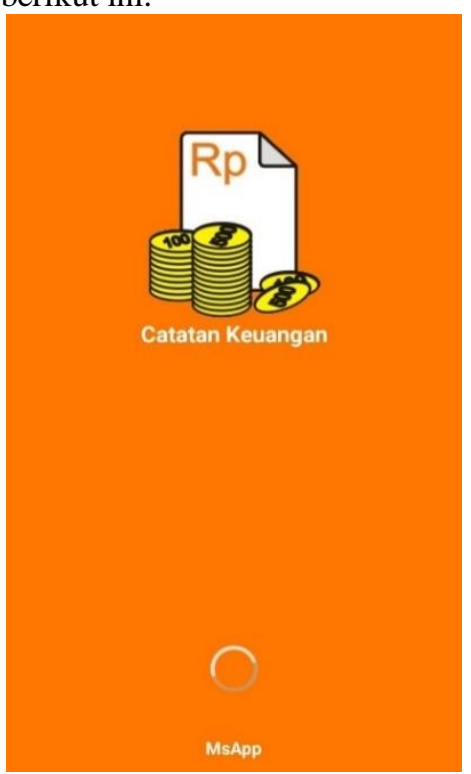

Gambar 6. Tampilan Awal Aplikasi 
b. Langkah berikutnya adalah memilih menu seperti tampak pada gambar 7 .

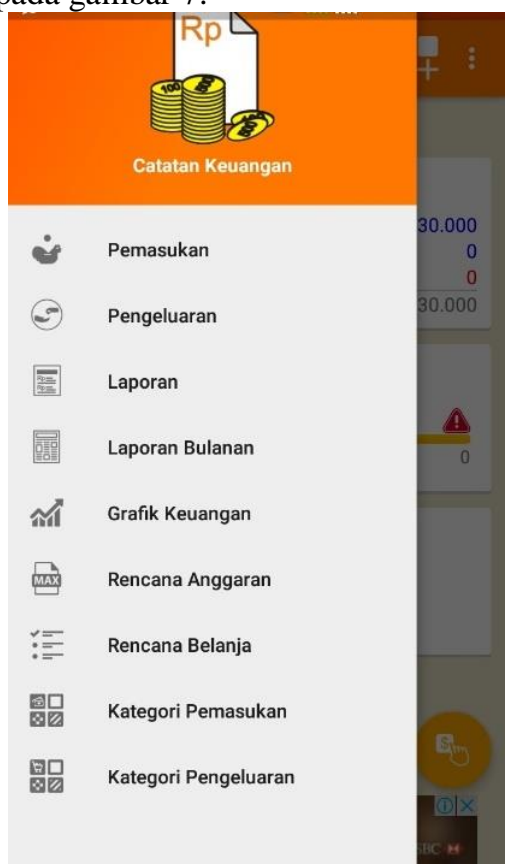

Gambar 7. Pemilihan Menu Aplikasi

c. Selanjutnya dapat membuat pencatatan keuangan sesuai dengan menu yang dipilih. Gambar 8 menampilkan pencatatan pemasukan.

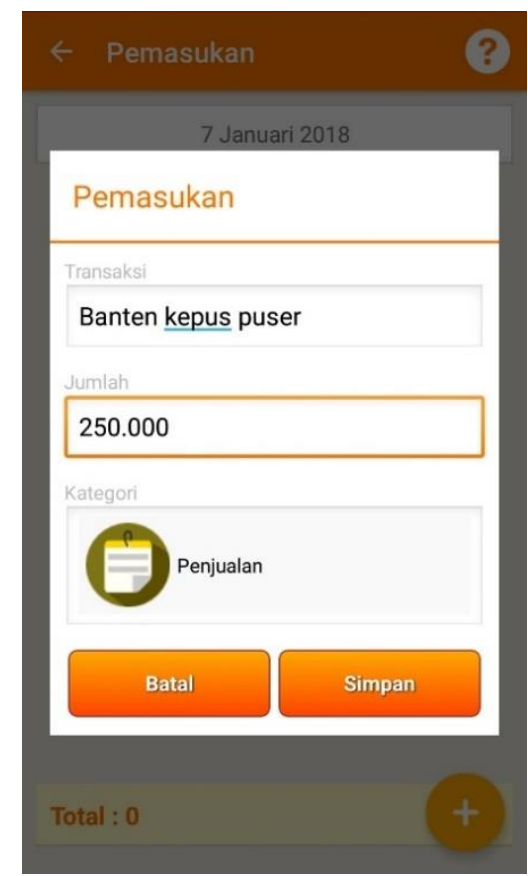

Gambar 8. Pencatatan Pemasukan

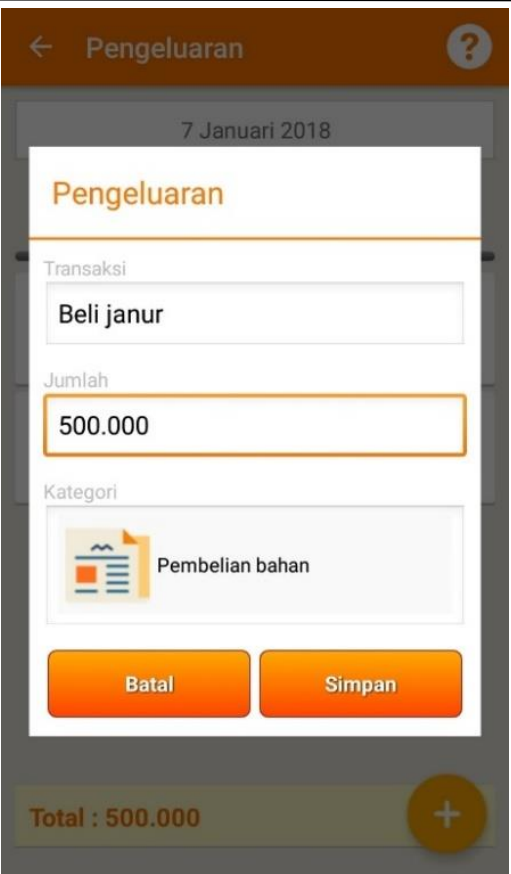

Gambar 9. Pencatatan Pengeluaran

Gambar 9 menampilkan pencatatan pengeluaran usaha banten.

d. Langkah selanjutnya yaitu membuat laporan keuangan

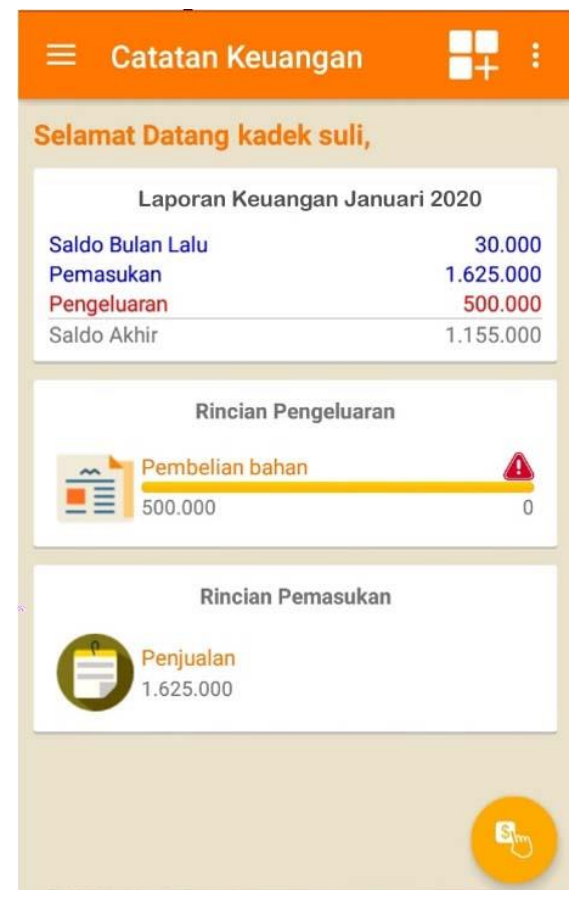

Gambar 10. Hasil Penncatatan Keuangan 
3. Monitoring dan Evaluasi

Kegiatan ini dilakukan untuk mengetahui kemampuan peserta setelah mengikuti pelatihan dan mengetahui manfaat yang dirasakan setelah kegiatan. Berdasarkan hasil pelatihan yang telah dipaparkan sebelumnya, kegiatan berupa pelatihan pemanfaatan aplikasi mobile untuk pencatatan keuangan ini mendapat respon yang positif dari mitra, dimana mitra sangat antusias dan tertarik mengikuti kegiatan, dan hasilnya juga sangat memuaskan. Sesuai hasil wawancara dengan mitra dan pengamatan secara langsung selama pelatihan berlangsung, kegiatan pengabdian masyarakat ini memberikan hasil berupa pemanfaatan aplikasi mobile untuk pencatatan keuangan dan pembuatan laporan bulanan, sehingga dapat mengetahui laba/rugi usahanya

4. Penutupan

Sesi terakhir adalah Journal of Technopreneurship and Information System penutupan yang diisi dengan mengambil dokumentasi.

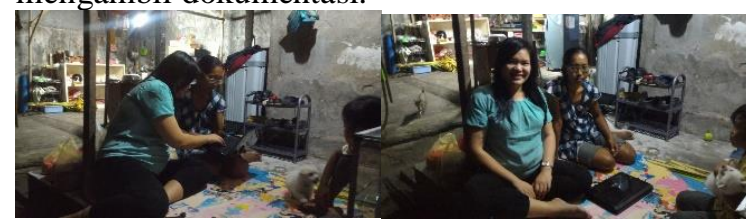

Gambar 11. Dokumentasi Kegiatan

\section{KESIMPULAN}

Berdasarkan hasil kegiatan pengabdian masyarakat ini, maka dapat disimpulkan sebagai berikut:

1. Sesuai dengan hasil wawancara, dapat disimpulkan bahwa kini Ibu Kadek Suli dapat mengetahui dan memahami pemanfataan aplikasi mobile selain untuk hiburan saja.

2. Ibu Kadek Suli dapat memanfaatkan aplikasi mobile untuk pencatatan keuangan dan pembuatan laporan bulanan.

3. Ibu Kadek Suli dapat mengetahui laba/rugi usahanya berdasarkan laporan bulanan yang dibuat.

\section{UCAPAN TERIMAKASIH}

Kami mengucapkan terima kasih yang sebesar-besarnya kepada Mitra Pengabdian Masyarakat yang telah mendukung kegiatan dan kami ucapkan terima kasih pula kepada tim reviewer dan semua pihak yang telah bersedia untuk menerima artikel ini.

\section{DAFTAR PUSTAKA}

Andarsari, P. R. and Dura, J. (2018) 'Implementasi Pencatatan
Keuangan pada Usaha Kecil dan Menengah', Jurnal JIBEKA, 12(1), p. 59. doi: 10.32812/jibeka.v12i1.16.

Gunanto, D. S. (2015) 'Peranan Laporan Keuangan Dalam Rangka Memberdayakan dan Mengembangkan Usaha Mikro Kecil dan Menengah di Kabupaten Sukoharjo', Jurnal Akuntansi dan Pajak, 16(1), p. 103. doi: 10.29040/jap.v16i01.25.

Ismanto, E., Novalia, M. and Herlandy, P. B. (2017) 'Pemanfaatan Smartphone Android sebagai Media Pembelajaran bagi Guru SMA Negeri 2 Kota Pekanbaru', Jurnal Untuk Mu Negeri, 1(1), p. 42. doi: 10.37859/jpumri.v1i1.33.

Nasution, J. A., Neviyarni, S. and Alizamar. (2017) 'Motif Siswa memiliki Smartphone dan Penggunaannya', Jurnal Penelitian Pendidikan Indonesia, 3(2), p. 15. doi: 10.29210/02017114.

Rinandiyana, L. R., Kusnandar, D. L. and Rosyadi, A. (2020) 'Pemanfaatan Aplikasi Akuntansi berbasis Android (SIAPIK) untuk Meningkatkan Administrasi Keuangan UMKM', Jurnal Qardhul Hasan, 6(1), p. 73. doi: 10.30997/qh.v6i1.2042.

Juhardi, U., Khairullah (2019) 'Sistem Pencatatan dan Pengolahan Keuangan pada Aplikasi Manajemen Keuangan E-Dompet Berbasis Android', (JTIS), p. 24. doi: 10.36085/jtis.v2i1.215. 